\title{
Pengaruh Pupuk Kombinasi Urea - Zeolit - Arang Aktif (UZAA) terhadap pH, Eh, Amonium dan Nitrat pada Tanah Sawah Rancaekek, Kabupaten Bandung
}

\author{
Restiana Maulinda ${ }^{1}$, Maya Damayani ${ }^{2}$, dan Benny Joy ${ }^{2}$ \\ 1) Alumni Program Studi Agroteknologi Fakultas Pertanian UNPAD \\ 2) Departemen Ilmu Tanah dan Sumberdaya Lahan, Fakultas Pertanian, UNPAD \\ Jl. Raya Bandung Sumedang Km 21 Jatinangor \\ Korespondensi: restianamaulinda@gmail.com
}

\begin{abstract}
Urea is $N$ fertilizer that often used by Indonesian's famers. Zeolite and activated charcoal is known to be able to increase efficiency Nitrogen from urea fertilizer on paddy soils. This research was conducted to study the urea-zeolite-activated charcoal fertilizer combination for acidity ( $p H)$, Redox Potential (Eh) level, slow release $\mathrm{NH}_{4}{ }^{+}$(ammonium) and $\mathrm{NO}_{3}$ (nitrate) on paddy soils. Experiment was carried out at greenhouse and experimental field, Departement of Soil Science and Land Resources Management, Faculty of Agriculture, Universitas Padjadjaran, Jatinangor. The experimental design was Randomized Block Design consisted of five treatments and five replications. The treatments consisted of A (control), B (50\% Urea $+25 \%$ Zeolite $+25 \%$ Activated charcoal), C (50\% Urea + 45\% Zeolite $+5 \%$ Activated charcoal), D (60\% Urea $+40 \%$ Zeolite) and E (95\% Urea $+5 \%$ Zeolite). Experimental result showed that the application zeolite and activated charcoal increased the $\mathrm{pH}$ and decreasead Eh level. Application of urea-zeolite-activated charcoal fertilizer (50\%:45\%:5\%) is the best for slow release ammonium. This experiment showed that application of Urea-Zeolite-Activated Charcoal (UZAA) fertilizer could reduce the usage of urea fertilizer.
\end{abstract}

Keyword: urea, zeolite, activated charcoal

\section{PENDAHULUAN}

Nitrogen merupakan salah satu unsur hara esensial yang dibutuhkan tanaman dalam jumlah besar. Unsur Nitrogen $(\mathrm{N})$ di dalam tanah berasal dari dekomposisi bahan-bahan organik seperti hewan atau sisa tanaman, aplikasi pemupukan seperti urea dan amonium nitrat, udara, dan air hujan. Nitrogen diserap oleh tanaman dalam bentuk amonium $\left(\mathrm{NH}_{4}{ }^{+}\right)$ dan nitrat $\left(\mathrm{NO}_{3}^{-}\right)$. Amonium dapat dimanfaatkan oleh tanaman secara optimal dibandingkan dengan nitrat, hal ini dikarenakan nitrat lebih mudah tercuci dan lebih memungkinkan untuk terbentuknya $\mathrm{N}_{2} \mathrm{O}$ dari proses denitrifikasi. Nitrogen diserap oleh tanaman melalui akar dan stomata daun saat hujan atau penyemprotan pupuk daun (Hanafiah, 2005).

Urea $\left(\mathrm{CO}\left(\mathrm{NH}_{2}\right)_{2}\right)$ merupakan jenis pupuk $\mathrm{N}$ yang banyak digunakan oleh petani padi di Indonesia. Permasalahan yang dihadapi dalam penggunaan pupuk urea adalah efisiensi pupuk yang rendah sehingga kebutuhan nitrogen tanaman sulit terpenuhi. Efisiensi pupuk $\mathrm{N}$ yang rendah disebabkan oleh adanya proses- proses nitrifikasi, denitrifikasi, volatilisasi, imobilisasi, pencucian dan fiksasi amonium. Usaha yang dapat dilakukan untuk mengurangi kehilangan unsur $\mathrm{N}$ dari pupuk adalah dengan memodifikasi pupuk $\mathrm{N}$ dalam bentuk pupuk lambat tersedia (slow release).

Salah satu cara untuk modifikasi pembuatan pupuk lambat tersedia adalah dengan mencampur bahan yang sukar larut dalam air serta melapisi pupuk dengan bahan tertentu sehingga penglepasan pupuk dalam tanah menjadi lambat (Pratomo, dkk., 2009). Pupuk dalam bentuk lepas lambat dapat mengoptimalkan penyerapan nitrogen dikarenakan dapat mengendalikan pengelepasan unsur nitrogen sesuai dengan waktu dan jumlah yang dibutuhkan dan dapat mempertahankan keberadaan nitrogen di dalam tanah (Nainggolan dkk., 2009).

Zeolit dan arang aktif merupakan bahanbahan yang sukar larut dalam air sehingga dapat digunakan sebagai bahan campuran untuk pembuatan pupuk lepas lambat. Zeolit merupakan mineral yang memiliki kapasitas 
tukar kation (KTK) yang tinggi (80-180 me /100g), sehingga zeolit memiliki kemampuan yang tinggi dalam pertukaran kation-kation. Arang aktif merupakan bahan amelioran yang mengandung carbon (C) yang sangat tinggi yaitu $85-95 \%$ dan memiliki kapasitas tukar kation yang tinggi sehingga mampu mengikat kation-kation tanah yang dapat bermanfaat bagi pertumbuhan tanaman (Jamilah, 2014).

Penambahan zeolit dan arang aktif ke dalam tanah dapat merubah sifat-sifat kimia pada tanah seperti potensial redoks (Eh) dan keasaman $(\mathrm{pH})$ tanah. Zeolit mampu memperbaiki $\mathrm{pH}$ pada tanah sehingga zeolit dapat dimanfaatkan untuk meningkatkan $\mathrm{pH}$ tanah masam (Suwardi, 2009). Zeolit mengandung basa alkali seperti $\mathrm{K}^{+}, \mathrm{Na}^{+}, \mathrm{Ca}^{+}$, dan $\mathrm{Mg}^{2+}$ (Setiadi dan Pertiwi, 2007) sedangkan permukaan pada arang aktif memiliki gugus kimia seperti karbonil, asam karboksilat, lakton, fenol, dan eter sehingga mempengaruhi perubahan nilai $\mathrm{pH}$ tanah. Penggenangan yang dilakukan pada tanah sawah juga menyebabkan perubahan-perubahan sifat kimia tanah antara lain penurunan potensial redoks (Eh) dan perubahan $\mathrm{pH}$ pada tanah.

Penelitian ini bertujuan untuk mengetahui pengaruh aplikasi pupuk urea, zeolit, dan arang aktif (UZAA) terhadap perubahan nilai $\mathrm{pH}$, nilai potensial redoks (Eh) serta penglepasan amonium $\left(\mathrm{NH}_{4}^{+}\right)$dan nitrat $\left(\mathrm{NO}_{3}^{-}\right)$ pada tanah sawah.

\section{BAHAN DAN METODE}

Percobaan ini dilaksanakan di Rumah Kaca Kebun Percobaan Tanah dan Air Departemen Ilmu Tanah dan Sumberdaya Lahan dan Laboratorium Kesuburan Tanah dan Nutrisi Tanaman Fakultas Pertanian, Unpad, Jatinangor. Rancangan percobaan yang digunakan adalah Rancangan Acak Kelompok (RAK) yang terdiri dari 5 perlakuan dan 5 ulangan (Tabel 1). Perlakuan yang digunakan dalam penelitian ini adalah pupuk tablet kombinasi urea, zeolit, dan arang aktif (UZAA).
Tabel 1 Daftar Pupuk Kombinasi Urea, Zeolit, dan Arang

\begin{tabular}{cccc}
\hline \multirow{2}{*}{ Perlakuan } & \multicolumn{3}{c}{ Persentase Campuran } \\
\cline { 2 - 4 } & Urea & Zeolit & $\begin{array}{c}\text { Arang } \\
\text { aktif }\end{array}$ \\
\cline { 2 - 4 } A (Kontrol) & 0 & 0 & 0 \\
B & 50 & 25 & 25 \\
C & 50 & 45 & 5 \\
D & 60 & 40 & 0 \\
E & 95 & 5 & 0 \\
\hline
\end{tabular}

Bahan yang digunakan pada percobaan ini terdiri dari urea, zeolit, arang aktif, tanah sawah Rancaekek, aquades, dan bahan kimia untuk analisis $\mathrm{pH}$, Eh, amonium, nitrat.

Tanah sawah asal Rancaekek dikeringanginkan terlebih dahulu kemudian dihaluskan dan disaring hingga berukuran $2 \mathrm{~mm}$. Tanah yang sudah halus ditimbang seberat $1 \mathrm{~kg}$ dan dimasukkan ke dalam polibeg $12 \times 20 \mathrm{~cm}$, lalu tanah dibuat dalam lumpur. Setelah itu pupuk urea-zeolit-arang aktif dimasukkan ke dalam tanah sawah sedalam $3 \mathrm{~cm}$, dan kemudian disiram menggunakan aquades hingga keadaan tergenang. Lalu dilakukan pengamatan sebanyak empat kali yaitu pada 7, 14, 21, dan 28 hari.

Pengamatan yang dilakukan adalah analisis $\mathrm{pH}$, potensial redoks (Eh), amonium, dan nitrat. Analisis dilakukan perminggu dengan pengambilan sampel tanah dari polibeg. Tanah yang berada dalam polibeg dimasukkan ke dalam ember, kemudian tanah diaduk hingga merata. Tanah yang sudah homogen diambil seberat \pm 500 gram untuk dikeringanginkan, tanah diambil secara komposit. Kemudian tanah dikeringanginkan dan dihaluskan dengan menggunakan lumpang dan alu.

Analisis amonium dan nitrat menggunakan metode destilasi, pengukuran $\mathrm{pH}$ menggunakan $\mathrm{pH}$ meter, dan potensial redoks menggunakan potensiometer. Analisis data secara statistik dilakukan dengan menggunakan program SPSS versi 16.0. Uji F pada taraf nyata 5\% dilakukan untuk melihat pengaruh perlakuan. Apabila pengaruh perlakuan berbeda nyata, maka 
dilanjutkan dengan uji Duncan Multiple Range Test pada taraf nyata $5 \%$.

\section{HASIL DAN PEMBAHASAN}

\subsection{Analisis Kandungan Pupuk}

Berdasarkan hasil analisis pendahuluan (Tabel 2), tersebut diperoleh data bahwa urutan pupuk yang memiliki kadar $\mathrm{N}$ dari yang tertingi hingga terendah secara berurutan adalah $\mathrm{E}>\mathrm{D}>\mathrm{C}>\mathrm{B}$. Kandungan $\mathrm{N}$-total tertinggi dimiliki oleh perlakuan perlakuan E (95\% Urea + 5\% Zeolit) sebesar 42,36\%. Semua pupuk perlakuan menunjukkan kadar nitrogen total yang lebih dari $20 \%$. Oleh karena itu, semua pupuk perlakuan sudah memenuhi syarat kelayakan pupuk menurut Balai Penelitian Tanah (2004).

Tabel 2 Hasil Analisis Laboratorium

\begin{tabular}{ccccc}
\multicolumn{5}{c}{ Kandungan N pada Pupuk UZAA } \\
\hline $\begin{array}{c}\text { Perla- } \\
\text { kuan }\end{array}$ & $\mathbf{N - o r g}$ & $\mathbf{N H}_{4}{ }^{+}$ & $\mathbf{N O}_{3^{-}}$ & $\begin{array}{c}\text { N- } \\
\text { Total }\end{array}$ \\
\cline { 2 - 5 } & $---------------------\% 0^{---------------~}$ \\
\hline B & 22,08 & 0,60 & 0,85 & 23,53 \\
C & 22,54 & 1,08 & 1,12 & 24,74 \\
D & 25,48 & 0,71 & 0,89 & 27,08 \\
E & 40,81 & 0,80 & 0,75 & 42,36 \\
\hline
\end{tabular}

\subsection{Nilai pH Tanah}

Nilai pH berkisar kurang dari 7 disebut masam, nilai $\mathrm{pH}$ lebih dari 7 disebut basa, dan nilai $\mathrm{pH} 7$ disebut netral. Pengukuran $\mathrm{pH}$ dilakukan setiap satu minggu selama 4 minggu pengamatan. Hasil analisis $\mathrm{pH}$ tanah menunjukkan terjadinya perubahan $\mathrm{pH}$ selama perlakuan. Berdasarkan hasil uji statistik bahwa nilai $\mathrm{pH}$ tanah tiap perlakuan menunjukkan perbedaan yang nyata pada uji jarak Duncan taraf 5\%. Nilai pH pada Tabel 3 menunjukkan peningkatan pada masingmasing perlakuan yang sebelumnya agak masam menjadi basa selama 4 minggu pengamatan.

Pengamatan pada minggu pertama perlakuan D memiliki nilai $\mathrm{pH}$ tertinggi namun tidak berbeda nyata dengan perlakuan E. Perlakuan E pada minggu kedua dan ketiga memiliki nilai $\mathrm{pH}$ tertinggi namun berbeda nyata dengan perlakuan lainnya. Perlakuan E pada minggu keempat memiliki nilai $\mathrm{pH}$ tertinggi namun berbeda nyata dengan perlakuan A. Perlakuan E dengan kandungan zeolit paling sedikit terjadi peningkatan $\mathrm{pH}$ yang tinggi hal ini disebabkan adanya proses perubahan nitrogen dari amonium karbamat menjadi amonium yang melepaskan ion $\mathrm{OH}^{-}$.

Tabel 3 Perubahan pH selama 4 Minggu Setelah Perlakuan

\begin{tabular}{ccccc}
\hline \multirow{2}{*}{$\begin{array}{c}\text { Perla- } \\
\text { kuan }\end{array}$} & $\begin{array}{c}\text { Ninggu } \\
\text { I }\end{array}$ & $\begin{array}{c}\text { Minggu } \\
\text { II }\end{array}$ & $\begin{array}{c}\text { Minggu } \\
\text { III }\end{array}$ & $\begin{array}{c}\text { Minggu } \\
\text { IV }\end{array}$ \\
\hline $\mathrm{A}$ & $5,74 \mathrm{a}$ & $5,90 \mathrm{a}$ & $6,12 \mathrm{a}$ & $6,39 \mathrm{a}$ \\
$\mathrm{B}$ & $6,83 \mathrm{~b}$ & $6,85 \mathrm{~b}$ & $7,05 \mathrm{~b}$ & $7,37 \mathrm{~b}$ \\
$\mathrm{C}$ & $6,89 \mathrm{~b}$ & $6,90 \mathrm{~b}$ & $7,20 \mathrm{~b}$ & $7,38 \mathrm{~b}$ \\
$\mathrm{D}$ & $7,36 \mathrm{c}$ & $7,17 \mathrm{~b}$ & $7,50 \mathrm{c}$ & $7,71 \mathrm{~b}$ \\
$\mathrm{E}$ & $7,31 \mathrm{c}$ & $7,63 \mathrm{c}$ & $7,77 \mathrm{~d}$ & $7,81 \mathrm{~b}$ \\
\hline Keterangan : Angka yang diikuti oleh huruf yang sama \\
\multicolumn{5}{c}{ secara vertikal tidak berbeda nyata } \\
menurut uji jarak berganda Duncan 5\%
\end{tabular}

Menurut Cyio (2008), peningkatan nilai $\mathrm{pH}$ terjadi karena adanya penglepasan ion $\mathrm{OH}^{-}$ yang dapat meningkatkan $\mathrm{pH}$ tanah karena terjadi keseimbangan antara ion $\mathrm{H}^{+}$dengan ion $\mathrm{OH}^{-}$baik dari perubahan feri menjadi fero maupun nitrat menjadi nitrit yang keduanya memberi kontribusi gugus hidroksil ke dalam larutan tanah.

Perubahan $\mathrm{pH}$ juga terjadi karena adanya pencampuran dari zeolit dan arang aktif pada pupuk. Penambahan zeolit dan arang aktif pada perlakuan dapat memperbaiki nilai $\mathrm{pH}$ tanah yang masam, hal ini dikarenakan kandungan zeolit yang terdiri dari basa alkali seperti $\mathrm{K}^{+}$, $\mathrm{Na}^{+}, \mathrm{Ca}^{+}$, dan $\mathrm{Mg}^{2+}$ yang dapat menggantikan kedudukan $\mathrm{H}^{+}$dalam kompleks jerapan, sehingga $\mathrm{pH}$ tanah meningkat. Penggunaan arang aktif dikarenakan terdapat gugus kimia pada permukaan arang aktif seperti karbonil, asam karboksilat, lakton, fenol, dan eter yang berpengaruh terhadap perubahan $\mathrm{pH}$ tanah. 
Perlakuan A tanpa aplikasi pupuk UZAA menunjukkan adanya perubahan $\mathrm{pH}$ akibat penggenangan. Perubahan nilai $\mathrm{pH}$ dapat disebabkan juga karena adanya proses penggenangan selama proses inkubasi. Menurut Ponnamperuma (1978), penggenangan meingkatkan nilai $\mathrm{pH}$ tanah masam dan menurunkan $\mathrm{pH}$ tanah alkali, sehingga $\mathrm{pH}$ tanah masam dan alkali akan berada pada $\mathrm{pH}$ antara 6 dan 7 setelah penggenangan (De Datta, 1981).

\subsection{Nilai Potensial Redoks (Eh)}

Potensial redoks (Eh) merupakan ukuran kuantitatif ketersediaan elektron dan menunjukkan intensitas oksidasi atau reduksi dalam sistem kimia maupun biologi (Patrick dan Gambrell, 1989). Menurut Garrels dan Christ (1965) dalam Tan (1992), potensial redoks tanah bervariasi dengan kondisi reduksi dan oksidasi dalam tanah serta berkaitan dengan $\mathrm{pH}$ tanah. Pengukuran Eh merupakan parameter yang penting untuk menentukan sifat elektrokimia suatu tanah sawah atau tanah tergenang (Situmorang dan Sudadi, 2001).

Hasil analisis Eh menunjukkan adanya perubahan nilai Eh selama 4 minggu pengamatan. Berdasarkan hasil uji statistic (Tabel 4), nilai Eh tanah tiap perlakuan menunjukkan perbedaan yang nyata pada uji jarak Duncan 5\%. Pengamatan pada minggu pertama perlakuan D memiliki nilai Eh terendah namun tidak berbeda nyata dengan perlakuan C. Perlakuan D pada minggu kedua memiliki nilai Eh terendah namun berbeda nyata dengan perlakuan E. Pengamatan pada minggu ketiga menunjukkan semua perlakuan tidak berbeda nyata.

Penurunan nilai Eh pada tanah dapat disebabkan karena adanya kontribusi penambahan bahan organik pada perlakuan. Bahan organik yang digunakan adalah penggunaan arang aktif. Bahan organik akan melepas ion $\mathrm{OH}^{-}$karena terjadi proses reduksi sehingga meyebabkan keseimbangan antara $\mathrm{H}^{+}$ dengan ion $\mathrm{OH}^{-}$baik dari perubahan feri menjadi fero maupun dari nitrat menjadi nitrit (Starr 1986 dalam Cyio, 2008). Menurut Cyio (2008), bahan organik dapat memberi keseimbangan terhadap aktivitas ion $\mathrm{H}^{+}$yang menyebabkan menurunya konsentrasi ion $\mathrm{H}^{+}$, sehingga menyebabkan berkurangnya jumlah elektron dalam larutan tanah yang berpengaruh terhadap penurunan nilai Eh.

Tabel 4 Perubahan Eh selama 4 Minggu Setelah Perlakuan

\begin{tabular}{ccccc}
\hline $\begin{array}{c}\text { Perla- } \\
\text { kuan }\end{array}$ & Minggu I & Minggu II & $\begin{array}{c}\text { Minggu } \\
\text { III }\end{array}$ & $\begin{array}{c}\text { Minggu } \\
\text { IV }\end{array}$ \\
\hline A & 267,60 b & 231,80 ab & 194,40 a & $169,60 \mathrm{c}$ \\
B & 258,60 ab & 235,60 ab & 190,60 a & $164,20 \mathrm{ab}$ \\
C & 251,00 a & 237,20 ab & 191,40 a & 165,20 bc \\
D & 250,80 a & 228,80 a & 191,40 a & 160,00 a \\
E & 265,80 b & 238,80 b & 190,60 a & 160,40 a \\
\hline Keterangan : Angka yang diikuti oleh huruf yang sama \\
secara vertikal tidak berbeda nyata \\
menurut uji jarak berganda Duncan 5\%
\end{tabular}

Bahan organik juga mempengaruhi laju penurunan Eh dikarenakan bahan organik merupakan sumber energi bagi mikroorganisme tanah. Menurut Sulaeman dkk. (1997), proses respirasi mikroorganisme tanah akan menghasilkan elektron sehingga kondisi larutan tanah semakin reduktif yang akan menyebabkan nilai Eh tanah menurun.

Menurut Situmorang dan Sudadi (2001), nilai Eh pada tanah tergenang jauh lebih rendah dibandingkan tanah berdrainase baik. Menurut Cyio (2008), proses penggenangan akan menyebabkan terjadi kekurangan oksigen dan penurunan tersebut akan diikuti dengan penurunan Eh, semakin lama tanah tergenang akan menyebabkan kekurangan oksigen tinggi dan semakin menurun nilai Eh. Menurut Arsana, dkk., (2003) terdapat hubungan negatif antara perubahan nilai Eh maka semakin naik nilai pH tanah (Tabel 3) maka semakin rendah nilai Eh (Tabel 4) sebaliknya jika semakin turun pH tanah maka nilai Eh akan semakin tinggi. 


\subsection{Kadar Amonium}

Hasil analisis amonium menunjukkan adanya perubahan konsentrasi amonium selama 4 minggu pengamatan. Hasil analisis uji statistik menunjukkan perbedaan signifikan terhadap penglepasan amonium pada tanah sehingga dilakukan uji lanjut Duncan pada taraf 5\%. Hasil uji statistik (Tabel 5) menunjukkan adanya pengaruh nyata antara masing-masing perlakuan pada tiap minggunya. Berdasarkan hasil tersebut menunjukkan bahwa pengaruh masing-masing perlakuan pupuk nitrogen terhadap pelepasan amonium terjadi hingga minggu keempat.

Tabel 5 Pengaruh Perlakuan Pupuk terhadap Konsentrasi Amonium yang dilepaskan tiap Minggu

\begin{tabular}{ccccc}
\hline $\begin{array}{c}\text { Perla- } \\
\text { kuan }\end{array}$ & $\begin{array}{c}\text { Nilai Eh } \\
\text { Minggu } \\
\text { I }\end{array}$ & $\begin{array}{c}\text { Minggu } \\
\text { II }\end{array}$ & $\begin{array}{c}\text { Minggu } \\
\text { III }\end{array}$ & $\begin{array}{c}\text { Minggu } \\
\text { IV }\end{array}$ \\
\hline $\mathrm{A}$ & $0,09 \mathrm{a}$ & $0,12 \mathrm{a}$ & $0,38 \mathrm{a}$ & $0,24 \mathrm{a}$ \\
$\mathrm{B}$ & $0,23 \mathrm{~b}$ & $0,35 \mathrm{~b}$ & $0,98 \mathrm{~b}$ & $0,31 \mathrm{ab}$ \\
$\mathrm{C}$ & $0,24 \mathrm{bc}$ & $0,33 \mathrm{~b}$ & $0,29 \mathrm{a}$ & $0,23 \mathrm{a}$ \\
$\mathrm{D}$ & $0,27 \mathrm{~cd}$ & $0,30 \mathrm{~b}$ & $1,19 \mathrm{c}$ & $0,33 \mathrm{~b}$ \\
$\mathrm{E}$ & $0,30 \mathrm{~d}$ & $0,35 \mathrm{~b}$ & $1,65 \mathrm{~d}$ & $0,26 \mathrm{ab}$ \\
\hline
\end{tabular}

Keterangan : Angka yang diikuti oleh huruf yang sama secara vertikal tidak berbeda nyata menurut uji jarak berganda Duncan 5\%

Pengamatan pada minggu pertama sampai dengan minggu keempat, perlakuan A memiliki konsentrasi amonium terendah dibandingkan dengan perlakuan $\mathrm{B}, \mathrm{C}, \mathrm{D}$, dan $\mathrm{E}$ hal ini dikarenakan perlakuan A tidak diberikan pupuk nitrogen. Perlakuan A menunjukkan bahwa terjadi proses perubahan nitrogen di dalam tanah menjadi amonium namun ketersediaan amonium di dalam tanah lebih sedikit dibandingkan dengan perlakuan yang diberikan pupuk nitrogen.

Pengamatan pada minggu pertama perlakuan E memiliki konsentrasi amonium yang tertinggi dan berbeda nyata dengan perlakuan lainnya. Perlakuan E pada minggu kedua memiliki konsentrasi amonium yang tertinggi dan berbeda nyata dengan perlakuan
A. Pengamatan minggu ketiga perlakuan E memiliki konsentrasi amonium yang tertinggi namun berbeda nyata dengan perlakuan lainnya. Pengamatan minggu keempat perlakuan D memiliki konsetrasi amonium yang tertinggi dibandingkan dengan perlakuan lainnya. Pengamatan pada minggu pertama sampai dengan minggu keempat, perlakuan $\mathrm{A}$ memiliki konsentrasi amonium terendah dibandingkan dengan perlakuan $\mathrm{B}, \mathrm{C}, \mathrm{D}$, dan $\mathrm{E}$ hal ini dikarenakan perlakuan A tidak diberikan pupuk nitrogen.

Perubahan konsentrasi amonium yang terlarut dalam tanah akibat pemberian perlakuan pupuk UZAA disajikan pada Gambar 1. Perlakuan A mengalami peningkatan dan penurunan konsentrasi amonium di dalam tanah dikarenakan pada tanah sawah sudah terdapat unsur hara nitrogen yang berasal dari dekomposisi bahan-bahan organik, udara, dan lain-lain sehingga terjadi proses perubahan nitrogen di dalam tanah menjadi amonium namun ketersediaan amonium di dalam tanah lebih sedikit dibandingkan dengan perlakuan yang diberikan pupuk nitrogen.

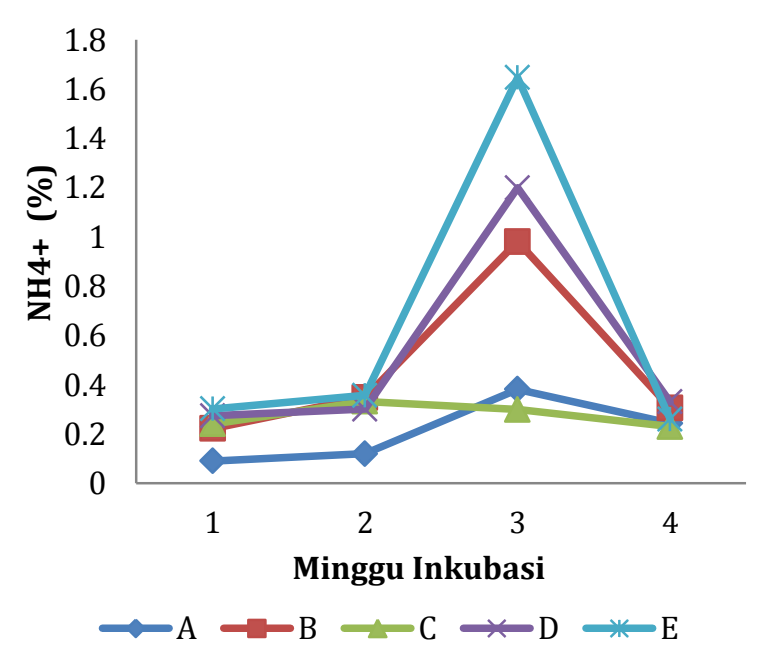

Gambar 1 Grafik Konsentrasi Amonium tiap Perlakuan per Minggu

Penglepasan amonium dari pupuk UZAA mengalami peningkatan secara serentak pada minggu kedua dan ketiga yang diduga terjadi akibat perubahan nitrogen menjadi 
ammonium. Hal ini dikarenakan penambahan amonium yang berasal dari proses hidrolisis urea. Peningkatan konsentrasi amonium tertinggi amonium berkurang dikarenakan adanya proses amonifikasi.

Perlakuan yang memiliki kadar amonium stabil hingga minggu keempat dimiliki oleh perlakuan C $(50 \%$ urea $+45 \%$ zeolit $+5 \%$ arang aktif) hal ini menunjukkan perlakuan tersebut mampu menjaga amonium untuk tetap tersedia pada tanah. Perlakuan C memperlihatkan adanya peranan dari zeolit dan arang aktif sehingga amonium yang dilepaskan oleh pupuk tidak mudah hilang dan berubah bentuk.

Kadar amonium yang masih tersedia dikarenakan adanya pencampuran antara zeolit dan arang aktif pada pupuk urea maka zeolit berperan untuk menjerap amonium, amonium yang dijerap zeolit dapat menghambat proses nitrifikasi sehingga amonium tidak segera dilepas ke dalam larutan tanah selama jumlah amonium dalam tanah masih tinggi. Menurut Suwardi (2000) zeolit mencegah terjadinya nitrifikasi karena mineral zeolit dapat menjerap amonium pada kisi-kisninya 3,9-5,4 ${ }^{\circ}$ A sedangkan diameter $\mathrm{NH}_{4}+1,4^{\circ} \mathrm{A}$, sehingga bakteri nitrifikasi tidak dapat masuk karena ukuran tubuh bateri 1000 kali lebih besar dari diameter rongga zeolit.

Penggunaan arang aktif mampu meningkatkan efisiensi pemupukan sampai $40 \%$, dikarenakan dengan adanya terjadi pada perlakuan E di minggu ketiga, hal ini dikarenakan perlakuan E jumlah zeolit yang dicampurkan kedalan pupuk urea hanya sedikit.

Menurut Nainggolan dkk. (2009), pengikatan amonium akan lebih efektif jika jumlah zeolit yang dicampurkan ke dalam pupuk semakin banyak hal ini dikarenakan kompleks jerapan yang dapat menangkap amonium semakin banyak. Penurunan konsentrasi amonium pada minggu keempat terjadi karena adanya proses perubahan amonium menjadi nitrat atau bentuk lainnya yang tidak tersedia dalam tanah. Sejalan dengan masa inkubasi jumlah pelapisan arang aktif pada pupuk urea dapat menjadikan pupuk urea slow release, tidak mudah menguap, tidak mudah larut atau tercuci (Nainggolan dkk., 2009; Jamilah, 2014).

\subsection{Kadar Nitrat}

Hasil analisis nitrat menunjukkan adanya perubahan konsentrasi nitrat selama 4 minggu pengamatan. Hasil analisis ragam pada taraf nyata $5 \%$ menunjukkan perbedaan signifikan terhadap konsentrasi nitrat pada empat minggu pengamatan. Konsentrasi nitrat pada tanah sawah menunjukkan adanya pengaruh nyata antara formulasi pupuk UZAA pada masing-masing perlakuan di tiap minggunya (Tabel 6).

Tabel 6 Pengaruh Perlakuan Pupuk terhadap Konsentrasi Nitrat yang dilepaskan tiap Minggu

\begin{tabular}{ccccc}
\hline \multirow{2}{*}{$\begin{array}{c}\text { Perla- } \\
\text { kuan }\end{array}$} & \multicolumn{4}{c}{ Konsentrasi Nitrat (\%) } \\
\cline { 2 - 5 } & $\begin{array}{c}\text { Minggu } \\
\text { I }\end{array}$ & $\begin{array}{c}\text { Minggu } \\
\text { II }\end{array}$ & $\begin{array}{c}\text { Minggu } \\
\text { III }\end{array}$ & $\begin{array}{c}\text { Minggu } \\
\text { IV }\end{array}$ \\
\hline $\mathrm{A}$ & $1,33 \mathrm{c}$ & $0,29 \mathrm{~b}$ & $0,35 \mathrm{c}$ & $0,11 \mathrm{~b}$ \\
$\mathrm{~B}$ & $1,57 \mathrm{~d}$ & $1,16 \mathrm{~d}$ & $0,14 \mathrm{a}$ & $0,06 \mathrm{a}$ \\
$\mathrm{C}$ & $1,52 \mathrm{~d}$ & $0,16 \mathrm{a}$ & $0,20 \mathrm{ab}$ & $0,05 \mathrm{a}$ \\
$\mathrm{D}$ & $0,63 \mathrm{~b}$ & $0,13 \mathrm{a}$ & $0,22 \mathrm{~b}$ & $0,04 \mathrm{a}$ \\
$\mathrm{E}$ & $0,36 \mathrm{a}$ & $0,35 \mathrm{c}$ & $0,18 \mathrm{ab}$ & $0,03 \mathrm{a}$ \\
\hline
\end{tabular}

Keterangan : Angka yang diikuti oleh huruf yang sama secara vertikal tidak berbeda nyata menurut uji jarak berganda Duncan 5\%

Pengamatan minggu pertama, perlakuan yang memiliki konsentrasi tertinggi adalah perlakuan $B$ namun tidak berbeda nyata dengan perlakuan C. Pada minggu kedua perlakuan yang memiliki konsentrasi tertinggi adalah perlakuan B namun berbeda nyata dengan perlakuan lainnya. Pengamatan minggu ketiga perlakuan yang memiliki konsentrasi nitrat tertinggi adalah perlakuan A namun berbeda nyata dengan perlakuan lainnya. Pengamatan minggu keempat perlakuan yang memiliki konsentrasi nitrat tertinggi adalah perlakuan A namun berbeda nyata dengan perlakuan lainnya. 
Perubahan konsentrasi nitrat pada tanah sawah akibat pengaplikasian pupuk UZAA pada minggu kesatu hingga minggu keempat ratarata mengalami penurunan, disajikan pada Gambar 2.

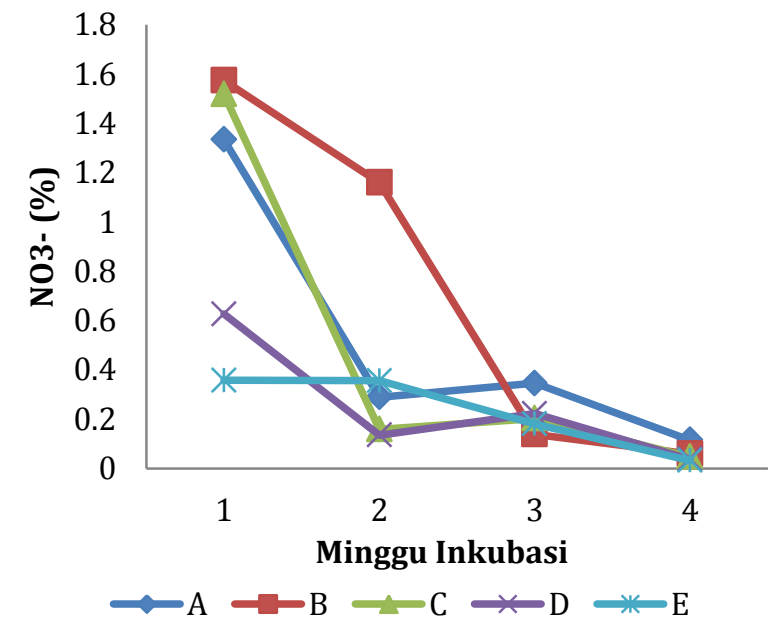

Gambar 2 Grafik Konsentrasi Nitrat pada setiap Perlakuan per Minggu

Penurunan dan peningkatan konsentrasi nitrat berkesinambungan dengan konsentrasi amonium yang terdapat pada tanah dan berasal dari perubahan bentuk atau proses nitrifikasi amonium menjadi nitrat (Kania, dkk., 2014). Perlakuan A tanpa diberikan pupuk nitrogen terjadi proses perubahan amonium menjadi nitrat dikarenakan di dalam tanah sudah mengandung unsur nitrogen sehingga terjadi proses nitrifikasi.

Konsentrasi nitrat tertinggi terdapat pada perlakuan B. Menurut Leiwakabessy (1998) dalam Hikmah, dkk., (2006) konsentrasi nitrat berhubungan dengan ketersediaan amonium dalam larutan maka jika ketersediaan amonium tinggi maka nitrat akan mengalami peningkatan, hal ini dikarenakan amonium merupakan bahan baku untuk proses nitrifikasi.

\section{KESIMPULAN}

Penggunaan zeolit dan arang aktif pada tanah sawah berpengaruh terhadap peningkatan nilai pH dan penurunan nilai Eh.
Pengaplikasian pupuk kombinasi Urea-ZeolitArang Aktif (50\% : 45\% : 5\%) merupakan formula terbaik dalam melepas amonium secara lambat.

\section{DAFTAR PUSTAKA}

Arsana, Dana., S. Yahya., A. P. Lontoh., dan H. Pane. 2003. Hubungan antara penggenangan dini dan potensi redoks, produktivitas etilen dan pengaruhnya terhadap pertumbuhan dan hasil padi (Oryza sativa) sistem tabela. Bul. Agro 31(2): 37-41.

Cyio, M. B. 2008. Efektivitas bahan organik dan tinggi genangan terhadap perubahan Eh, $\mathrm{pH}$, dan status $\mathrm{Fe}, \mathrm{P}$, Al terlarut pada tanah Ultisol. J. Agroland, 15 (4): 257 263.

De Datta, S. K. 1981. Principles and Practices of Rice Production. John Wiley an Sons. New York.

Hanafiah, K. A. 2005. Dasar-Dasar Ilmu Tanah. Raja Grafindo Persada: Jakarta.

Hikmah, N., A. Sastiono., Suwardi., H. Saputra., M. Tandircung., M. Hamzah., D. Latiningsih., dan E. Pratolo. 2006. Studi slow release fertilizer (SRF): peranan zeolit dalam pelepasan nitrogen dari pupuk tersedia lambat (slow release fertilizer). Prosiding Seminar Nasional Zeolit V Bandar Lampung.

Jamilah. 2014. Pengaruh dosis urea dan arang aktif terhadap sifat kimia tanah dan pertumbuhan serta hasil padi sawah (Oryza sativa L.). Sains Riset 4 (1): 1 10.

Kania, S. S., Rija S., dan Hidayat S. 2014. Kelarutan N-organik, $\mathrm{N}-\mathrm{NH}_{4}{ }^{+}, \mathrm{N}-\mathrm{NO}_{3}{ }^{-}$, dan penjerapan Kadmium (Cd) pada formula pupuk campuran urea, zeolit, arang aktif, dan kanji dalam bentuk granul. Agri. Sci. J. I (4): 58-70. 
Kirk, R.E. and D.F. Othmer. 1964. Encyclopedia of Chemical Technology. The Intersience Inc, New York.Mason, C.F. 1993. Biology of Freshwater Pollution. Second Edition. Longman Scientific and Technical, New York. 351 p.

Nainggolan, Ganda Darmono., Suwardi., dan Darmawan. 2009. Pola pelepasan nitrogen dari pupuk tersedia lambat (slow release fertilizer) urea-zeolitasam humat. Prosiding Seminar Nasional Zeolit IV Bandung: 2-4 November 2009.

Ponnamperuma, F. N. 1978. Electrochemical changes in submerged soils and the growth of rice. In: IRRI. Soils and Rice. Los Banos. Philipppines.

Pratomo, K. R., Suwardi, dan Darmawan. 2009. Pengaruh pupuk slow release ureazeolit-asam humat (UZA) terhadap produktivitas tanaman padi var. Ciherang. Jurnal Zeolit Indonesia, 8 (2): 83-88.

Setiadi dan Pertiwi, A., 2007, Preparasi dan Karakterisasi Zeolit Alam untuk Konversi Senyawa ABE menjadi Hidrokarbon, Prosiding Konggres dan Simposium Nasional Kedua MKICS.

Situmorang, R dan Sudadi, U. 2001. Tanah Sawah. Jurusan Tanah, Fakultas Pertanian. Institut Pertanian Bogor. Bahan Kuliah.

Sulaeman., Evianti, dan J. S. Adiningsih. 1997. Pengaruh Eh dan terhadap sifat fosfat, kelarutan besi, dan hara lain pada tanah Hapludox Lampung. Prosiding Pertemuan Pembahasan dan Komunikasi Hasil. Penelitian Tanah dan Agroklimat. Bidang Kimia dan Biologi Tanah. Cisarua, Bogor 4 - 6 Maret 1997. Puslittanak, Bogor. Hal 1-18.

Suwardi. 2000. Pemanfaatan zeolit sebagai media tumbuh tanaman hortikultura.
Departemen Tanah, Fakultas Pertanian IPB, Prosiding. Temu Ilmiah IV. PPI. Tokyo, Jepang: 1-3 September 1995.

Tan, K. H. 1992. Dasar - Dasar Kimia Tanah. Gajah Mada University Press. Yogyakarta. 